\title{
The Effects of Reduced Caloric Intake and Increased Insulin-Induced Caloric Intake on the Cell Growth of Muscle, Liver, and Cerebrum and on Skeletal Collagen in the Postweanling Rat ${ }^{[3]}$
}

\author{
Joan E. Graystone and Donald B. GheeK ${ }^{[44]}$ \\ Division of Growth, The Children's Medical and Surgical Center, \\ The Johns Hopkins University School of Medicine, Baltimore, Maryland, USA
}

Extract

Following weaning, Sprague Dawley rats were given $60 \%$ of a normal Purina chow intake until 7 weeks of age. There was a reduced DNA content in the cerebrum at 49 days of age. Previous failure to demonstrate reduced DNA content in rat brain during undernutrition could relate to preoccupation with whole brain analysis. The present study indicates that cerebral DNA increases in normal rats after weaning.

The cell size or the ratio of protein: DNA increased in the muscle tissues of rats subjected to the caloric restriction, while the ratio of RNA:DNA increased in all tissues studied. These findings are contrary to those found in protein deficiency per se. Carcass weight, fat, and water were below expected levels, but skeletal collagen was less affected.

Rats from 26 to 38 days of age, given an increased insulin-induced caloric intake, showed an excess weight gain per gram of food consumed per day and an excess growth of muscle and fat. In contrast, cerebral weight, water, protein, DNA, and RNA content were reduced possibly because of periodic hypoglycemia.

\section{Speculation}

Following weaning, rats subjected to sustained caloric restriction have reduced cell numbers for age and are said not to reach expected cell populations on rehabilitation. With caloric restriction, growth hormone may no longer be effective at the cellular level, but insulin activity continues. Although the ratio of cytoplasm:nucleus is maintained, DNA replication is minimal. Alternatively, since DNA content in the cerebrum decreases, hypothalamic or acidophilic cells may be lost, and growth hormone production may be insufficient for adequate DNA replication and somatic growth.

When protein is restricted, the failure of cells to increase in size may be associated with atrophy of the pancreas and a decrease in insulin production.

\section{Introduction}

Malnutrition is widespread throughout the world. There have been many studies of metabolic changes in tissues [26]. Dickerson et al. [15] found that under- nutrition in the sucking pig from 2 weeks to one year of age produced a decrease in DNA synthesis in the brain, which failed to attain expected levels after rehabilitation.

Winick and NoBle [37] studied the effects of restrict- 
ed nutrition in rats prior to weaning and for 21 days after weaning. Prior to weaning, all organs showed a reduction in weight, DNA, RNA, and protein content without a change in the ratio of protein:DNA. They concluded that there was a reduction of cell number (DNA) without alteration of cell size (protein:DNA). Rehabilitation did not restore the cell number to expected levels. In the postweaning period (21 to 42 days of age) and with $50 \%$ of a normal caloric intake, the same changes were found again, but there was no reduction of DNA content in lung or brain. Refeeding was accompanied by recovery in weight of these two organs. The final result was an animal retarded in overall growth but with normal size brain and lung. Dickerson and WALMSLEy [16] studied undernourished rats from 3 to 11 weeks of age. The weight of the brain was appropriate for the weight of the animal, and there was no reduction in DNA content.

ElLiorT and CHEEK [17] found that rats from 3 to 6 weeks of age given $50 \%$ of normal caloric intake (Purina chow diet) showed an actual loss of DNA content in the two tissues examined-muscle and liver. Other, as yet unpublished, studies [4] have shown that following a one-week period of hypoxia with associated restricted nutrition, DNA content of rat brain may be normal at the fifth week. DNA content of the cerebrum, however, decreased, while that of thecerebellum increased when comparison was made with control animals.

The present study investigated nucleic acid and protein content of cerebrum, liver, muscle, and carcass of rats subjected to caloric restriction in the postweaning period from 23 to 49 days. For contrast, observations on rats of the same age that were exposed to an excessive caloric intake induced by injection of protamine zinc insulin are reported.

\section{Methods}

Sprague Dawley male rats were obtained at 21 days of age [39] and placed in individual metabolic cages at 23 days of age. They received Purina chow (23\% protein) ad libitum. Tap water was freely available. Groups IA to IE were killed at 26, 28, 35, 38, and 49 days of age, respectively. Group II (calorie-restricted) rats were also used as pair-fed controls to hypophysectomized rats in a subsequent study [6].

Group III rats received a chow diet ad libitum and $5 \%$ sucrose water for drinking. Subcutaneous injections of protamine zinc insulin were given from the 26 th day of age. The dosages of insulin for each day were $0.4,0.4,0.6,0.6,0.84,0.90,1.04,1.2,1.2,1.5$ and 1.8 units, respectively. Groups consisted of 6 to 9 animals. Each animal was weighed daily, at which time the food and fluid intake was monitored.

\section{Tissue Preparation}

Following ether anesthetization, the rats were killed by aortic puncture. The brain, liver, and a portion of the quadriceps muscle were removed immediately after exsanguination and the weights recorded. Weighed aliquots of tissue were taken for chemical determinations, frozen immediately, and stored at $-20^{\circ}$ before analysis. The remaining tissue was then dried to constant weight at $95^{\circ}$ to determine water content. The muscle sample was extracted for fat with petroleum ether ( $40-60^{\circ}$ boiling point) and dried again to constant weight [10]. The skinned, eviscerated carcass, minus feet, was dried to constant weight at $95^{\circ}$. Fat was removed by repeated extractions with petroleum ether [10], and the fat-free carcass was dried to constant weight before being reduced to a 40 -mesh powder with a Wiley Mill.

\section{Chemical Analyses}

$D \mathcal{N A}$. Samples of brain, liver, and muscle were homogenized in a sufficient amount of trichloroacetic acid $(0.3 \mathrm{~N})$ so that $0.2 \mathrm{ml}$ of the homogenate contained approximately $6 \mathrm{mg}$ of brain and muscle and $2.5 \mathrm{mg}$ of liver. Three aliquots of the homogenate were then assayed for DNA content according to the fluorometric technique of KisSANE and RoBbins [23]. Calf thymus DNA [40] was used to prepare the standard DNA solutions. The recovery of added DNA to 20 respective homogenates was $99.98 \pm 3.70 \%$ for brain, $100.41 \pm$ $3.51 \%$ for muscle, and $102.06 \pm 3.91 \%$ for liver. All readings were obtained on the Zeiss Spectrofluorometer with an Osram XBO 1 Xenon arc lamp as light source.

Protein. Nitrogen content of the trichloroacetic acid homogenate was determined by the Conway microdiffusion technique following digestion with acid as described previously $[10,12]$. Protein concentration was calculated using the 6.25 conversion factor.

$R \mathcal{N} A$. Extraction of RNA was performed by the modified Schmidt Thannhauser technique described by Munro and FleGK [29]. Approximately $50 \mathrm{mg}$ of fresh tissue was required for the determination. The extract was then assayed for ribose by orcinol reaction. RNA content was calculated by reference to the optical density of the color produced by standard RNA solutions, containing 2 to $20 \mu \mathrm{g}$ of yeast RNA [41] under identical conditions. Recovery of known amounts of RNA added to 20 homogenates was $100.68 \pm 3.67 \%$.

Metals. $\mathrm{Ca}$ and $\mathrm{K}$ were determined in certain tissues using the Perkin Elmer Atomic Absorption Spectrophotometer [7].

Muscle Mass. Carcass, in this study, refers to the eviscerated rat without skin or feet. The estimated muscle mass was calculated as follows [8]: 
Muscle mass, $\mathrm{g}=$

mg carcass noncollagen protein content

$\%$ dried solid in muscle

It is assumed that noncollagen protein plus muscle water equals muscle mass. Protein and collagen contents of carcass were determined by methods previously described [8,9]. The weight of the muscle sample was added to the value for muscle mass obtained by analysis of the residual carcass.

Two additional methods for the appraisal of muscle mass were undertaken in a group of 38-day-old control rats.

The potassium content of carcass and of fresh muscle was determined. Assuming that all carcass potassium is contained in the musculature, muscle mass was calculated [8]. A closer estimate can be obtained using the

formula: Muscle mass, $\mathrm{g}=\frac{\text { carcass } \mathrm{K}-\text { skeletal } \mathrm{K}}{\mathrm{mg} \mathrm{K} / \mathrm{g} \text { muscle }}$,

where skeletal $\mathrm{K}=$ skeletal mass $\times \mathrm{mg} \mathrm{K} / \mathrm{g}$ bone.

Also assuming that the calcium content of carcass is derived from the skeleton, a value for muscle mass can be calculated by subtracting the estimated skeletal mass from the carcass weight. To achieve this, a portion of the rat femur was removed and the calcium content of the bone and carcass determined. Thus, skeletal mass, $\mathrm{g}=\frac{\mathrm{mg} \mathrm{Ca} \text { of carcass }}{\mathrm{mg} \mathrm{Ca} / \mathrm{g} \text { bone }}$.

The values obtained for the various methods are shown in table I. There was no statistical difference between the three methods when compared with the noncollagen method, but comparison of the predicted muscle mass using the potassium method, first with, then without correction for bone potassium, did yield two sets of data that differed significantly.

Table I. Comparison between four methods for estimating muscle mass in the male Sprague-Dawley rat (38 days of age)

\begin{tabular}{|c|c|c|c|c|}
\hline & \multicolumn{4}{|c|}{ Basis of estimation } \\
\hline & $\begin{array}{l}\text { Non- } \\
\text { collagen } \\
\text { protein }\end{array}$ & Calcium & $\begin{array}{l}\text { Potas- } \\
\text { sium }\end{array}$ & $\begin{array}{l}\text { Potas- } \\
\text { sium } \\
\text { (cor- } \\
\text { rected) }\end{array}$ \\
\hline Mean (g) & 44.06 & 43.55 & 46.93 & 41.37 \\
\hline $\mathrm{SD}$ & 1.55 & 2.01 & 4.50 & 4.23 \\
\hline $\mathrm{N}$ & 6 & 6 & 6 & 6 \\
\hline$\frac{\mathrm{SD}^{1}}{\text { Mean }} \times 100$ & 3.52 & 4.61 & 9.59 & 10.22 \\
\hline
\end{tabular}

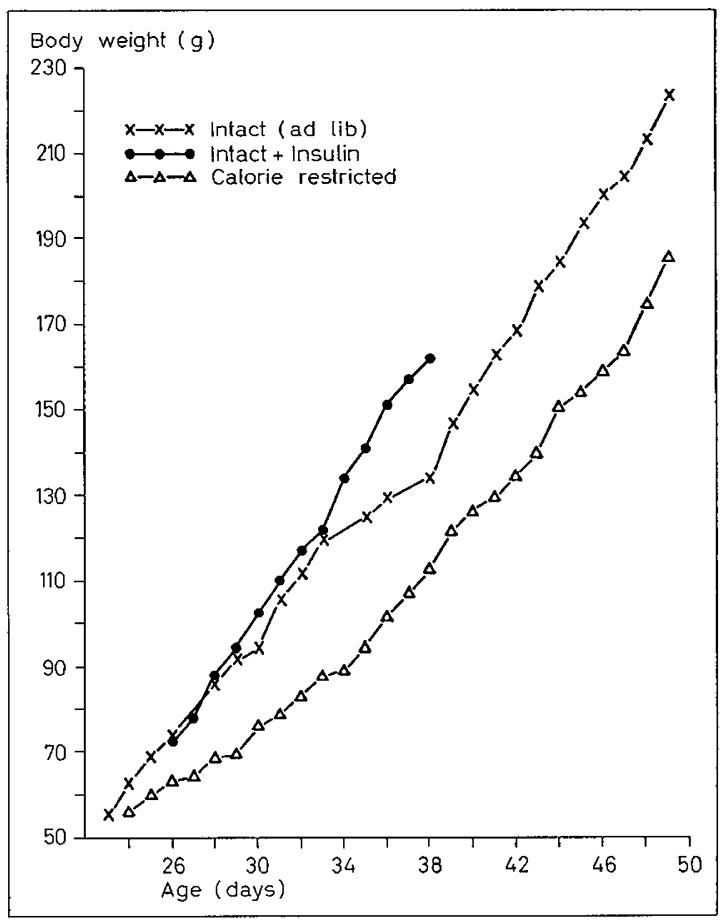

Fig. 1. The progressive increments in body weight for rats 23 to 49 days of age receiving $60 \%$ of a chow diet ad libitum, for rats receiving an ad libitum diet plus increasing doses of insulin, and for rats reared on a calorie-restricted diet.

Muscle Cell Population. It is assumed that DNA content of the specimen of muscle taken from the quadriceps is a measure of nuclear number of muscle. Hence, muscle cell population $=$ No. of cells (or nuclei) per gram $\times$ grams of muscle mass; or, DNA in the muscle mass $\div 6.2$ picograms $(\mathrm{DNA} /$ nucleus $)=$ muscle cell population. Statistical comparisons were made with the Student ' $t$ ' test.

\section{Results}

\section{Body Weight and Food Intake}

Daily weights of the three groups of rats are given in figure 1. Weight increments and data relating to protein and calorie intake are shown in table II.

At 38 days of age, the calorie-restricted rats reached a weight of $119 \mathrm{~g}$ compared with $147 \mathrm{~g}$ for the control group. At 49 days of age, the restricted rats weighed $186 \mathrm{~g}$ and the control group, $224 \mathrm{~g}$. From 26 to 38 days of age, the restricted rats received $308 \pm 12$ calories, while the intake of the control group was $532 \pm 60$. From 39 to 49 days of age, the comparable values were 
caloric intake on the cell growth of muscle, liver, and cerebrum and on skeletal collagen...

Table II. Dietary intake

\begin{tabular}{|c|c|c|c|c|c|c|c|}
\hline & & $\begin{array}{l}\text { Age } \\
\text { days }\end{array}$ & $\begin{array}{c}\text { Body } \\
\text { weight } \\
\mathrm{g}\end{array}$ & $\begin{array}{l}\text { Dietary } \\
\text { intake } \\
\mathrm{g} / 100 \mathrm{~g} \\
\mathrm{BW}^{1} / \text { day }\end{array}$ & $\begin{array}{l}\text { Relative } \\
\text { weight } \\
\text { increase }^{2}\end{array}$ & $\begin{array}{l}\text { Caloric } \\
\text { intake }^{3}\end{array}$ & $\begin{array}{c}\text { Protein } \\
\text { intake }(g)^{3}\end{array}$ \\
\hline \multicolumn{8}{|c|}{26 - to 38 -day period } \\
\hline \multirow[t]{3}{*}{ Normal } & mean & 38 & 146.7 & 16.0 & 0.37 & 532 & 47.4 \\
\hline & SD & & 6.2 & 2.4 & 0.04 & 60 & 5.4 \\
\hline & $\mathrm{N}$ & & 6 & 6 & 6 & 6 & 6 \\
\hline \multicolumn{8}{|c|}{ Calorie restricted } \\
\hline & mean & 38 & 119.4 & 11.5 & 0.38 & 308 & 27.4 \\
\hline & SD & & 3.5 & 0.7 & 0.03 & 12 & 1.05 \\
\hline & $\mathrm{N}$ & & 9 & 9 & 9 & 9 & 9 \\
\hline \multicolumn{8}{|c|}{ Intake (ad lib.) +insulin } \\
\hline & mean & 38 & 164.6 & 12.8 & 0.43 & 591 & 40.5 \\
\hline & $\mathrm{SD}$ & & 8.1 & 1.7 & 0.02 & 28 & 1.8 \\
\hline & $\mathrm{N}$ & & 8 & 8 & 8 & 8 & 8 \\
\hline \multicolumn{8}{|c|}{ 38- to 49 -day period } \\
\hline \multirow[t]{3}{*}{ Normal } & mean & 49 & 224.0 & 12.4 & 0.30 & 745 & 66.3 \\
\hline & $\mathrm{SD}$ & & 8.9 & 1.3 & 0.03 & 49 & 4.4 \\
\hline & $\mathrm{N}$ & & 7 & 7 & 7 & 7 & 7 \\
\hline \multicolumn{8}{|c|}{ Calorie restricted } \\
\hline & mean & 49 & 186.0 & 10.5 & 0.36 & 445 & 39.6 \\
\hline & $\mathrm{SD}$ & & 6.9 & 0.8 & 0.02 & 3 & 0.3 \\
\hline & $\mathrm{N}$ & & 8 & 8 & 8 & 8 & 8 \\
\hline \multicolumn{8}{|c|}{$\begin{array}{l}{ }^{1} \text { Body weight in } \mathrm{g} \text {. } \\
{ }^{2} \text { Grams of weight ix } \\
{ }^{3} \text { Caloric or protein }\end{array}$} \\
\hline
\end{tabular}

$444 \pm 3$ and $745 \pm 45$ calories, respectively. The restricted rats received $2.7 \mathrm{~g} / 100 \mathrm{~g} /$ day of protein, a satisfactory amount for growth [35]. The weight gains per gram of food ingested per day were similar for the calorie-restricted and control rats.

The rats that received insulin from 26 to 38 days of age gained $18 \mathrm{~g}$ more weight than did the control group ( $p<0.001)$. The caloric intake was significantly greater $(p<0.025)$ and the weight gain per gram of food per day was greater for this group $(\mathrm{p}<0.001)$.

\section{Carcass Composition}

In table III, data are recorded for body weight, fatfree carcass, carcass fat, protein, water, and skeletal collagen of the three groups of rats.

At 38 and 49 days of age, the calorie-restricted rats had less carcass weight, protein, water, and fat than did the control rats. Skeletal collagen was significantly reduced in the calorie-restricted group at 49 days of age but not at 38 days of age.

The rats that received insulin had significantly higher fat-free carcass weight $(p<0.01)$, carcass protein $(\mathrm{p}<0.02)$, water $(\mathrm{p}<0.005)$, and fat $(\mathrm{p}<0.001)$ than did control rats of the same age. Skeletal collagen, however, was not changed.

\section{Muscle, Liver, and Cerebrum}

In table III, data are also shown for muscle mass, muscle cell population, and the ratios of protein:DNA and RNA:DNA in muscle. Data for studies on liver and cerebrum are shown in tables IV and V, respectively.

\section{Calorie-Restricted Rats (Group II)}

Rats receiving $60 \%$ of a normal intake had a muscle mass $5 \mathrm{~g}$ less than that of controls at 38 days of age, and $25 \mathrm{~g}$ less at 49 days of age. The muscle cell number for normal 26- and 49-day-old rats was $6.08 \times 10^{9}$ and $13 \times 10^{9}$ respectively. The restricted rats showed little increase in the number of muscle cells, reaching a value of $6.4 \times 10^{9}$ at 49 days of age. There was, however, appreciable increase in the ratio of protein:DNA at 38 to 49 days of age if comparison was made with normal rats $(\mathrm{p}<0.001)$. 
Graystone, CheEk The effects of reduced caloric intake and increased insulin-induced

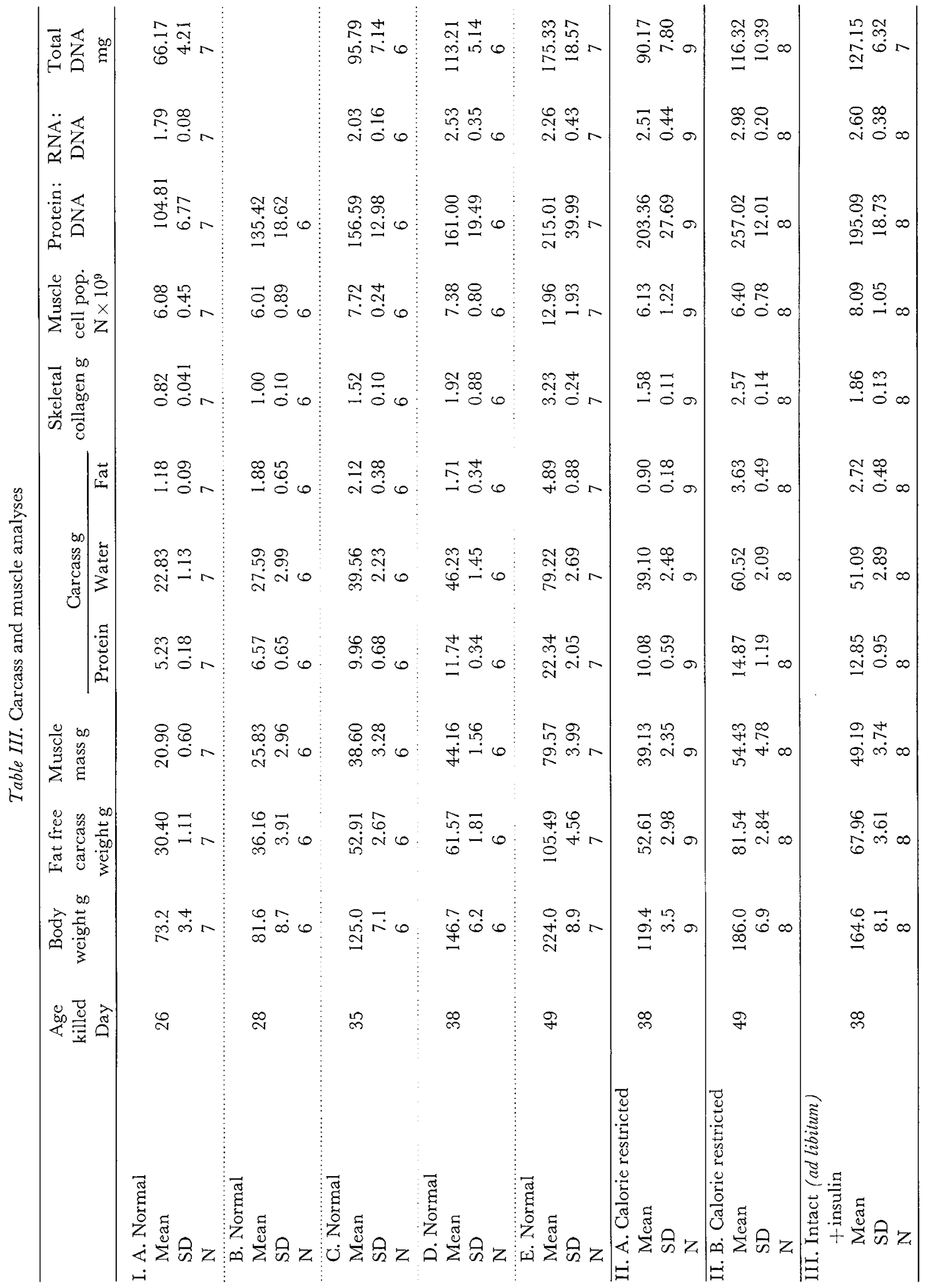


Table IV. Rat liver

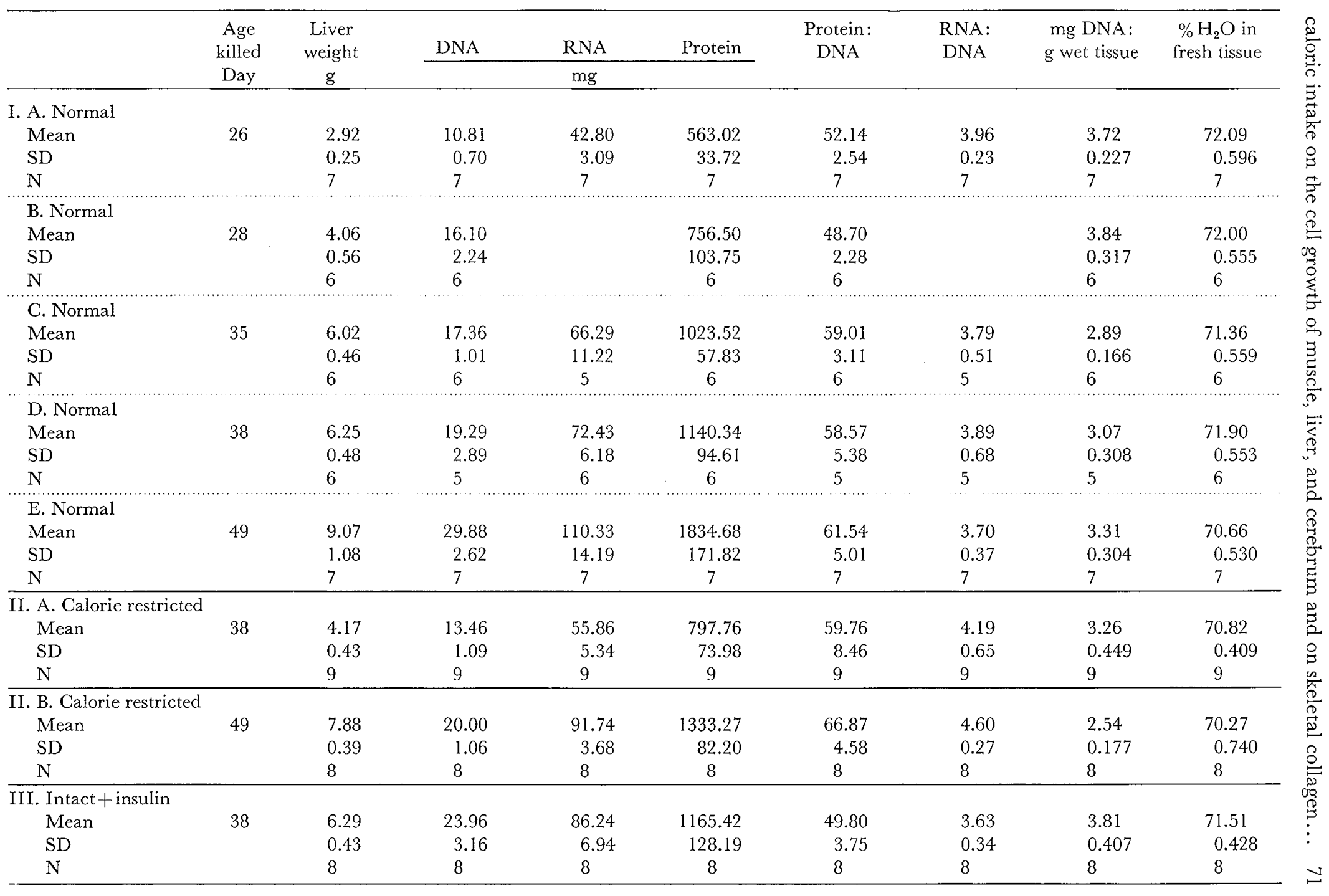


Graystone, Gheek The effects of reduced caloric intake and increased insulin-induced

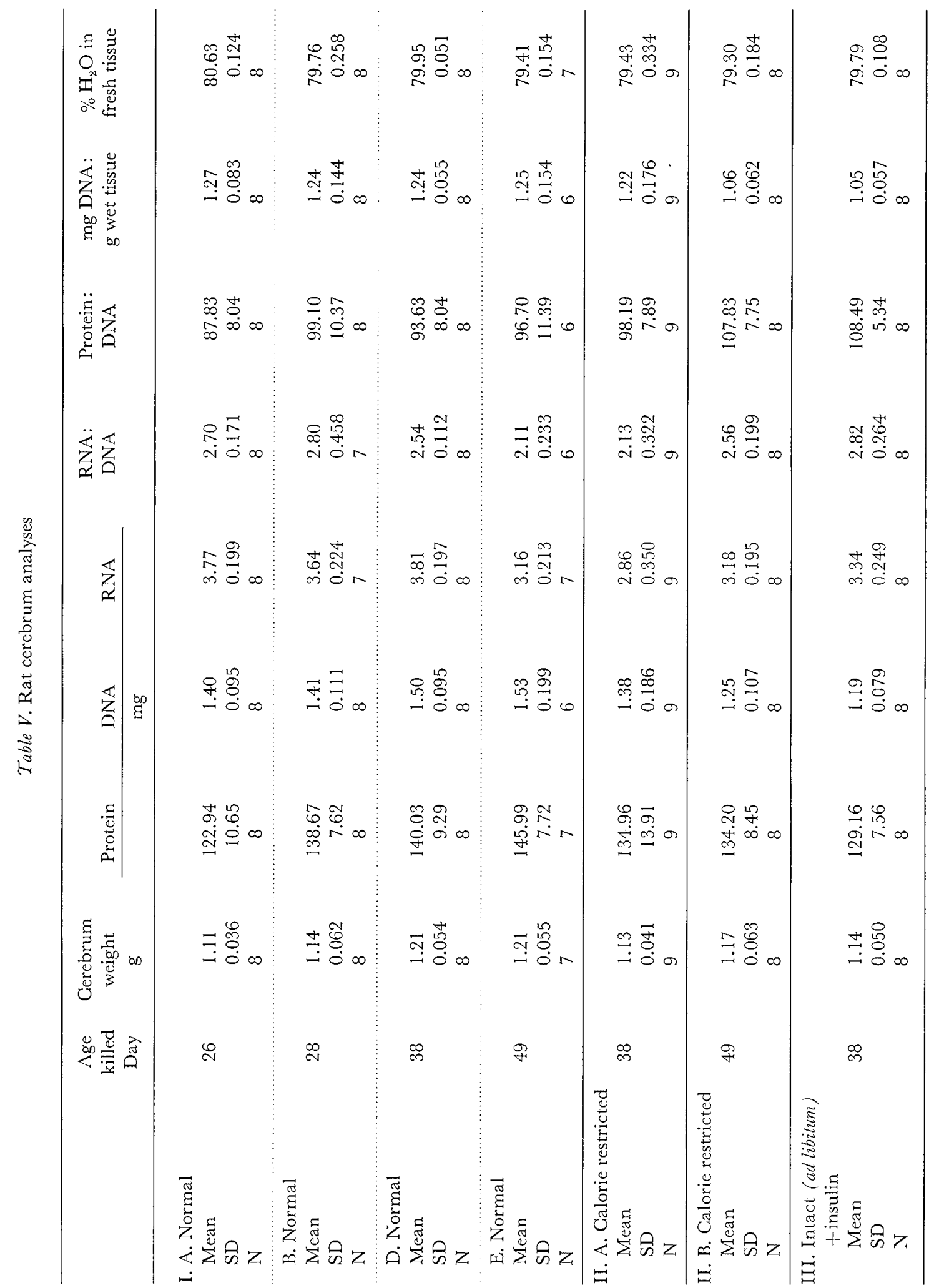


Total RNA content in the musculature equalled $116 \mathrm{mg}$ while that for the control rats was $175 \mathrm{mg}$ at 49 days of age. The concentration of DNA per gram of muscle was reduced to a greater extent; therefore, RNA per cell was high $(\mathrm{p}<0.001)$.

Values for liver weight and protein content (table IV) were reduced $(p<0.001)$. As with muscle, DNA content in liver was grossly reduced at 38 to 49 days of age, with a high ratio of RNA:DNA at 49 days of age $(p<0.001)$. The ratio of protein:DNA was the same as that for control rats. Total RNA content was $91.7 \mathrm{mg}$, significantly lower than the value of $110.3 \mathrm{mg}$ for controls $(p<0.005)$. Again, the increase in RNA per unit DNA in liver resulted mainly from a greater reduction of DNA content.

The weight and water content of the cerebrum was reduced at 38 days of age $(p<0.005)$. At 49 days of age, total RNA and DNA content was reduced $(\mathrm{p}<0.01)$. The ratio of protein:DNA showed no increase.

In all three tissues examined at 49 days of age, there was a failure of DNA synthesis, and the ratio of RNA: DNA was high. Only in muscle was the ratio of protein: DNA significantly increased.

\section{Rats Receiving Insulin (Group III)}

The findings in muscle and liver for rats that received insulin are summarized in figure 2. This group had a significant increase in muscle mass $(p<0.05)$ that was related to an increase in the ratio of protein: DNA ( $p<0.01)$, since no significant increase was found in muscle cell number. Total RNA content in muscle was also increased $(\mathrm{p}<0.001)$.

The weight of the liver and liver protein content of

Intact rat \pm insulin (26 to 38 days)
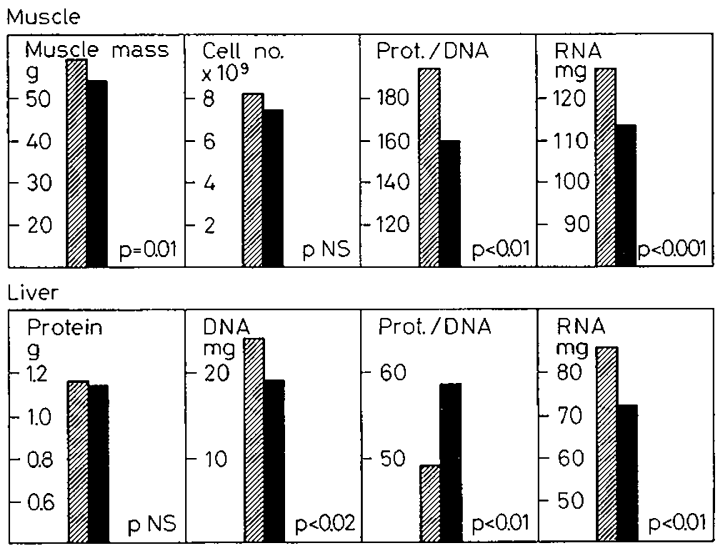

Fig. 2. The changes in cell number (DNA) and of cell size (protein/DNA) and of protein and RNA for muscle and liver in rats receiving insulin (shaded columns). The solid column represents control rats. the intact rats receiving insulin did not differ from that of the controls receiving a free diet. There was a rise in DNA ( $p<0.02)$ and RNA $(p<0.01)$ cortent of liver compared with that of controls and a fall in the ratio of protein:DNA $(p<0.01)$. The ratio of RNA:DNA did not change.

With respect to the cerebrum (table V), Group III rats had reduced cerebral weight $(p<0.01)$ and water content $(p<0.005)$. DNA content $(p<0.01)$ was also reduced, but the ratio of protein:DNA was increased $(p<0.001)$. Total RNA content also decreased $(p<$ 0.001 ), while the ratio of RNA:DNA increased ( $p$ $<0.01)$.

\section{Discussion}

With restriction of calories to $60 \%$ of normal while receiving adequate amounts of protein, growth in the rat during the postnatal period was retarded. This was particularly true of oxidative protoplasm; however, skeletal tissues were less affected. The present study showed that at 38 days of age, skeletal collagen was not reduced. A similar finding has been made with protein deprivation [28].

In this study, it was found that the DNA content of liver, muscle, and cerebrum was reduced after 26 days of caloric restriction. The failure of DNA to increase was constant. In the cerebrum, there was an actual reduction in DNA content at 49 days if a comparison was made with a 26-day-old normal rat. The finding of a reduced DNA content in liver or muscle of animals receiving restricted nutrition has been reported previously $[17,19,36]$.

In this study, DNA content of the cerebrum in rats during restricted nutrition varied with observations made by others $[16,37]$ on the DNA content of the whole brain. While total brain DNA content may reach stability at 18 days, cerebral DNA content increases until the 21st day [18]. The present data suggest that cellular growth of the cerebrum is not complete by the end of weaning. Since the cerebral cortex reaches stability at 18 days [1], this increase in DNA content may relate to subcortical or basal ganglia changes.

In the measurement of total brain DNA, the cerebellum accounts for a four-fold higher concentration than does the ccrebrum, and small changes in cerebral DNA per se could easily be missed. The method used here for DNA determination is specifically designed for brain tissue [23] and eliminates the interference from sialic acid [14] found in other methods employing the Dische reaction.

Perhaps cerebral cells are lost in the postweaning period with calorie restriction. Whether or not cells return with rehabilitation warrants further investigation [16]. In the postweaning period, rat brain should 
be an organ of minimal cell renewal [24]. The finding of normal brain DNA content following caloric restriction in the rat also remains unexplained [37].

Garrow [20] has demonstrated a loss of $\mathrm{K}^{40}$ from brains of children with kwashiorkor. There was a progressive return toward normal with rehabilitation [21]. Winick [38] found a reduced DNA content in postmortem brain specimens from marasmic infants.

Insulin induces hyperphagia in the rat [2], and an increase in somatic growth was observed in this study. The dosage of insulin was steadily increased according to the procedure of SALTER and BEST [32] for the hypophysectomized rat. It is possible that in these rats, significant episodic hypoglycemia was induced; this may have affected brain growth. Indeed, the weight of the cerebrum, together with the content of DNA, RNA, protein, and water, was reduced when compared with that of control rats of the same age.

Growth occurs primarily by increments in cell size and cell number. Calories are required to maintain tissues, basic metabolic rate, specific dynamic action, and activity. Under deleterious circumstances, however, the growth process would appear to be the first compromised. Comparable growth retardation was observed in rats subjected to an atmosphere of $10 \%$ oxygen from 3 to 6 weeks of age, and in pair-fed rats kept in room air [17]. Rats in room air maintained normal activity, but hypoxic rats remained motionless. Minimal increments of DNA content occurred in liver and muscle, while cell size increased. The calorierestricted rats described in this study exhibited similar growth failure.

Why increments in DNA or new cell formation ceases during caloric restriction is not apparent, but further growth in muscle would appear to be by protein accretion in existing cells. In muscle, elevation of RNA per cell may be meaningful, but in liver and cerebrum this elevation is not associated with an increased ratio of protein: DNA. The failure of DNA to increase questions the effectiveness of growth hormone at the tissue level $[3,6]$.

Hruza and FABRY [22] have shown that rats, previously calorie restricted, will return to expected weight only if given growth hormone during refeeding. They postulated a relative insufficiency of growth hormone to meet the needs for protein biosynthesis during refeeding. CHOw and LEE [11] produced growth-retarded offspring by restricting the diet of pregnant rats. After weaning, they were able to restore expected weight by injecting growth hormone over a three-week period.

Histologic studies indicate that the number of pituitary acidophil cells at maturity, following undernutrition, is proportional to the size of the mature rat [34]. The present findings speculate that if cerebral DNA is reduced in calorie restriction, possibly pituitary acidophil cells are also reduced in number; thus, the amount of growth hormone may be inadequate to provide for the necessary spurt in cell number, particularly when the animal reaches larger dimensions.

It is difficult to separate the effects of caloric restriction from those of protein restriction per se. MENDES and WATERLOW [25] found a reduction of the ratio of protein:DNA in liver and muscle of rats fed a $6 \%$ protein diet with minimal caloric restriction. A reduction in RNA content of cells and pancreatic atrophy have been reported in rats fed a protein-deficient diet [33]. In infants with protein malnutrition, MontGomERY [27] found morphologic evidence of reduced cell size. In more recent studies on the muscles of marasmic infants [5], it was found that the ratio of protein: DNA is grossly reduced, but in early rehabilitation, the increments in cell size were more remarkable than increments in nuclear number.

The rats in the present report were studied from weaning to adolescence (or sexual maturity) a time when somatic growth is maximal. The injection of insulin produced an augmented calorie intake and a greater weight gain per unit of food intake per day with increased weight of fat and muscle, but not of skeleton. Insulin induces hypoglycemia and the release of growth hormone, while food intake stimulates the release of both hormones [30]. The growth of muscle was due primarily to increments in the ratio of protein:DNA, which in turn was related to a high RNA content.

\section{Summary}

Groups of normal Sprague Dawley rats were studied from 23 to 49 days of age. Analyses were made of skeletal collagen, carcass fat, water, and protein at intervals during this period. An estimate of muscle mass was also calculated. In addition, the nucleic acid, protein, and water content was measured in liver, muscle and cerebrum.

The rats received a calorie-restricted diet from 23 days of age and similar analyses were made at 38 and 49 days of age.

It was found that caloric restriction (without protein deprivation) produced a reduction in DNA content and an increase in the ratios of RNA:DNA and protein:DNA in muscle. There was a reduction of RNA content in each tissue studied. An actual loss of DNA content in the cerebrum of the calorie-restricted rat was demonstrated at 49 days of age when compared with that of 26-day-old controls.

Rats subjected to an increased caloric intake, induced by daily injections of insulin, showed increased weight gain, carcass fat, muscle mass, and RNA content in tissue. The increase in muscle mass was related 
to an increase in the ratio of protein: DNA. Reduction of the protein, water, and nucleic acid content of the cerebrum reflect deleterious changes thought to result from periodic hypoglycemia.

\section{References and Notes}

1. Adams, D.H.: The relationship between cellular nucleic acids in the developing rat cerebral cortex. Biochem.J. 98: 635 (1966).

2. Beaton, J.R.; Feleki, V. and Stevenson, J.A.F.: Insular hyperphagia in rats fed a low-protein diet. Canad.J. Phys. Pharm. 43: 225 (1965).

3. CHeEk, D. B. : Cellular growth hormones, nutrition and time. Borden Award Address, October, 1967. Pediatrics 41: 30 (1968).

4. Cheer, D. B.: Unpublished data.

5. Cheek, D. B. and Graham, G.: Unpublished data.

6. Cheek, D.B. and Graystone, J. E.; The action of insulin, growth hormone, and epinephrine on cell growth in liver, muscle and brain of the hypophysectomized rat. Pediat. Res. 3: 77 (1969).

7. Cheek, D. B.; Powell, G. K.; Reba, R. and FeldMAN, M.: Mn., Cu., and $\mathrm{Zn}$ in rat muscle and liver cells and in thyroid and pituitary insufficiency. Bull. Johns Hopk. Hosp. 118: 338 (1966).

8. Cheek, D. B.; Powell, G.K. and Scort, R.E.: Growth of muscle mass and skeletal collagen in the rat. I. Normal growth. II. The effect of ablation of pituitary, thyroid or testes. Bull.Johns Hopk. Hosp. 116: 378 (1965).

9. Cheek, D.B.; Powell, G.K. and Scott, R.E.: Growth of muscle cells (size and number) and liver DNA in rats and Snell Smith mice with insufficient pituitary, thyroid, or testicular function. Bull.Johns Hopk. Hosp. 117: 306 (1965).

10. CHEek, D. B. and WEST, C.D.: Alterations in body composition with sodium loading and potassium restriction in the rat: The total body sodium, nitrogen, magnesium and calcium. J.clin. Invest. 35: 763 (1956).

11. Chow, B.F. and Cha-Sen Lee: Effect of dietary restriction of pregnant rats on body weight gain of the offspring. J. Nutr. 82: 10 (1964).

12. Conway, E.J.: Microdiffusion analysis and volumetric error, 3rd ed., chapt. 23 (Lockwood, London 1950).

13. Cooke, R.E.: Energy metabolism: Introduction; in Human growth (ed. CHEeK, D. B.) (Lea and Febiger, Philadelphia, Pa. 1968).

14. Croft, D.N. and Lubran, M.: The estimation of deoxyribonucleic acid in the presence of sialic acid: application to analysis of human gastric washings. Biochem.J. 95: 612 (1965).
15. Dickerson, J.W.T.; Dobbing, J. and McCance, R.A.: The effect of undernutrition on the postnatal development of the brain and cord in pigs. Proc. roy. Soc. Lond. 166: 396 (1967).

16. Digkerson, J.W.T. and Walmslex, A.L.: The effect of undernutrition and subsequent rehabilitation on the growth and composition of the central nervous system of the rat. Brain 90: 897 (1967).

17. Elliotr, D. A. and GheEk, D. B.: Muscle and liver cell growth in rats with hypoxia and reduced nutrition; in Human growth (ed. CHeEK, D. B.) (Lea and Febiger, Philadelphia, Pa. 1968).

18. FisH, I. and WINICK, M.: Presented at the meetings of the American Pediatric Society, Atlantic City, New Jersey, May (1968).

19. Fukuda, M. and Sibatani, A.: Biochemical studies on number and composition of liver cells in postnatal growth of the rat. J. Biochem. 40: 95 (1953).

20. Garrow, J.S.: Loss of brain potassium in Kwashiokor. Lancet ii: 643 (1967).

21. Garrow, J. S. : Personal communication.

22. HruZA, Z. and FABry, P.: Some metabolic and endocrine changes due to long lasting caloric undernutrition. Gerontologia 1: 279 (1957).

23. Kissane, J.M. and Robins, E.: The fluorometric measurement of deoxyribonucleic acid in animal tissues with special reference to the central nervous system. J. biol. Chem. 233: 184 (1958)

24. LeBlond, C.P.: Classifications of cell populations on the basis of their proliferative behavior. Nat. Cancer Inst. Monogr. 14: 119 (1964).

25. Mendes, C.B. and Waterlow, J.C.: The effect of a lowprotein diet, and of refeeding, on the composition of liver and muscle in the weanling rat. Brit.J. Nutr. 12: 74 (1958).

26. Metcoff, J.; Biochemical effects of protein-calorie malnutrition in man. Ann.Rev. Med. 18: 377 (1967).

27. Montgomery, R. D. : Muscle morphology in infantile protein malnutrition. J. clin. Path. 15: 511 (1962).

28. Montgomery, R.D.; Digkerson, J.W.T. and MaCANGE, R.A.: Severe undernutrition in growing and adult animals. Brit.J.Nutr. 18: 587 (1964).

29. Munro, H.N. and FleGK, A.: Recent development in the measurement of nucleic acids in biological materials (Suppl. review). Analyst 91: 78 (1966).

30. Rabinowitz, D. and Mérimée, T.J.: Peripheral actions and regulation of insulin and growth hormone secretion in intact man; in Human growth, (ed. Cheек, D. B.) (Lea and Febiger, Philadelphia, Pa. 1968).

31. Rose, H.E. and MAyer, J.: Activity, calorie intake, fat storage and the energy balance of infants. Pediatrics 41: 18 (1968). 
32. Salter, J. and Best, C.H.: Insulin as a growth hormone. Brit. med.J. ii: 354 (1953).

33. Svoboda, D.; Grady, H. and Hrgainson, J.: The effects of chronic protein deficiency in rats. Lab. Invest. 15: 731 (1966).

34. TAPlin, D.E.: The pituitary acidophils of nutritionally stunted rats. Proc. Austr. Phys. Soc. 45: 6 (1967).

35. WARNER, R.G.: Nutrient requirements of the laboratory rat; in Nutrient requirements of laboratory animals, pub. 990, p. 51 (National Academy of Sciences, National Research Council, Washington, D.C. 1962).

36. Williams, J.N., Jr.: Response of the liver to prolonged protein depletion. I. Liver weight, nitrogen and desoyribonucleic acid. J. Nutr. 73: 199 (1961).

37. Winick, M. and Noble, A.: Cellular response in rats during malnutrition at various ages. J. Nutr. 89: 300 (1966).

38. WinICK, M.: Personal communication.

39. Hormone Assay Laboratories, Chicago, Illinois. 40. Worthington Biochemical Corporation, Freehold, New Jersey.

41. Sigma Chemical Company, St.Louis, Missouri.

42. This work was supported by Grant HD 00126-05, from the National Institute of Child and Human Development, United States Public Health Service.

43. The authors acknowledge the technical assistance of Anna Mae Ortgies and Rachel Scott.

44. Requests for reprints should be addressed to: Donald B. Cheek, M.D., The Johns Hopkins Hospital, 601 North Broadway, Baltimore, Md. 21205 (USA). 